Article

\title{
Global Citizenship and Business Education, Part 1: Antecedents and Foundations
}

\author{
José R. de la Torre', Corinne B. Young ${ }^{2}$ \\ 1 University of Bologna Business School, Italy, and Florida International University (Emeritus), USA, ${ }^{2}$ Franklin University Switzerland, Switzerland \\ Keywords: global skills and values, global competency, sustainability, global citizenship
}

\section{AIB Insights}

Vol. 20, Issue 1, 2020

\begin{abstract}
Whereas national sovereignty persists as the primary form of political organization, the interconnectedness of today's world implies that any citizen's rights and obligations are no longer confined within national boundaries while many societal issues require global civic responses. Thus, business leaders need to be educated on the skills and values that characterize global citizenship in order for them to be accountable and act accordingly. This article traces the historical foundations of the concept of global citizenship, its definition and legitimacy. We also list the major skills and values that global citizens must possess in order to act accordingly.
\end{abstract}

\section{INTRODUCTION $^{1}$}

The rights, duties, and obligations of a citizen of any sovereign state are still fundamental to civil society. Nonetheless, the interconnectedness of today's world requires us to recognize that these rights and obligations may no longer be confined within national boundaries and that many global issues require global civic responses. Global citizenship, however, cannot be simply defined as an extension of the national concept to a global sphere. As Michael Byers (2005) writes, "Global citizenship empowers individual human beings to participate in decisions concerning their lives, including the political, economic, social, cultural and environmental conditions in which they live. It includes the right to vote, to express opinions and associate with others, and to enjoy a decent and dignified quality of life. It is expressed through engagement in the various communities of which the individual is a part, at the local, national and global level. And it includes the right to challenge authority and existing power structures - to think, argue and act with the intent of changing the world."

Nigel Dower (2005) encourages skeptics to at least acknowledge the individual's responsibility to making this world a better place by ensuring its continued existence. To the extent that certain issues transcend boundaries both morally and physically - only responsible global citizens can ensure the sustainability of the earth and its inhabitants. How then should global citizenship be defined? Where from does it derive its legitimacy? What does it mean for business leaders? How can it be taught and promoted? This essay will try to answer the first two questions; a companion piece, also included in this issue of AIB Insights, attempts to answer the last two.

\section{GLOBAL CITIZENSHIP THROUGHOUT HISTORY ${ }^{2}$}

The idea of individuals identifying with fellow human beings near and far has been with us for at least two millennia. The first recorded mention of a "citizen of the world" dates to classical Greece and the life of Diogenes (412-323 BCE). A self-appointed critic of Greek society, he taught that wisdom and happiness were inherent qualities independent of societal norms, and rejected family, political and social organizations, as well as property rights and reputation, as regressive characteristics of Athenian life. Diogenes is credited with the first use of the word "cosmopolitan"; when asked where he came from, he replied "I am a citizen of the world" (from kosmo - universe - and politês -citizen).

The Stoics, who flourished in Athens during the Hellenistic period, believed that goodness lies in the state of the soul itself, in wisdom and self-control. Accordingly, each individual "dwells ... in two communities - the local community of our birth, and the community of human argument and aspiration" (Nussbaum, 1997). To understand this view of cosmopolitanism one needs only to examine Hierocles' set of concentric circles that define a person's identity: the first circle is drawn around oneself, next comes our immediate family, then our extended family, followed by the neighborhood, fellow citizens and, at last, all humanity (Figure 1). The task of the world citizen is to "draw the circles in towards the center, making all human beings more like our fellow city dwellers" (Nussbaum, 1997), deserving our concern.

Early Christians were strongly influenced by these ideals. The division between the near citizens (belonging to the polis) and those distant (the cosmopolis) is made starker by the belief that whereas local government may have implicit divine authority, the most important work for human goodness is removed from any political sphere. Thus, the call to "Render unto Caesar the things that are Caesar's; and unto God the things that are God's" (Mathew, 22:21) lends

\footnotetext{
1 Some of these ideas were first presented at the Annual AIB Conference in Rio de Janeiro, Brazil, 2010.

2 This compact narrative is based on information derived from the Stanford Encyclopedia of Philosophy, the Great Books of the Western World, and Wikipedia.
} 


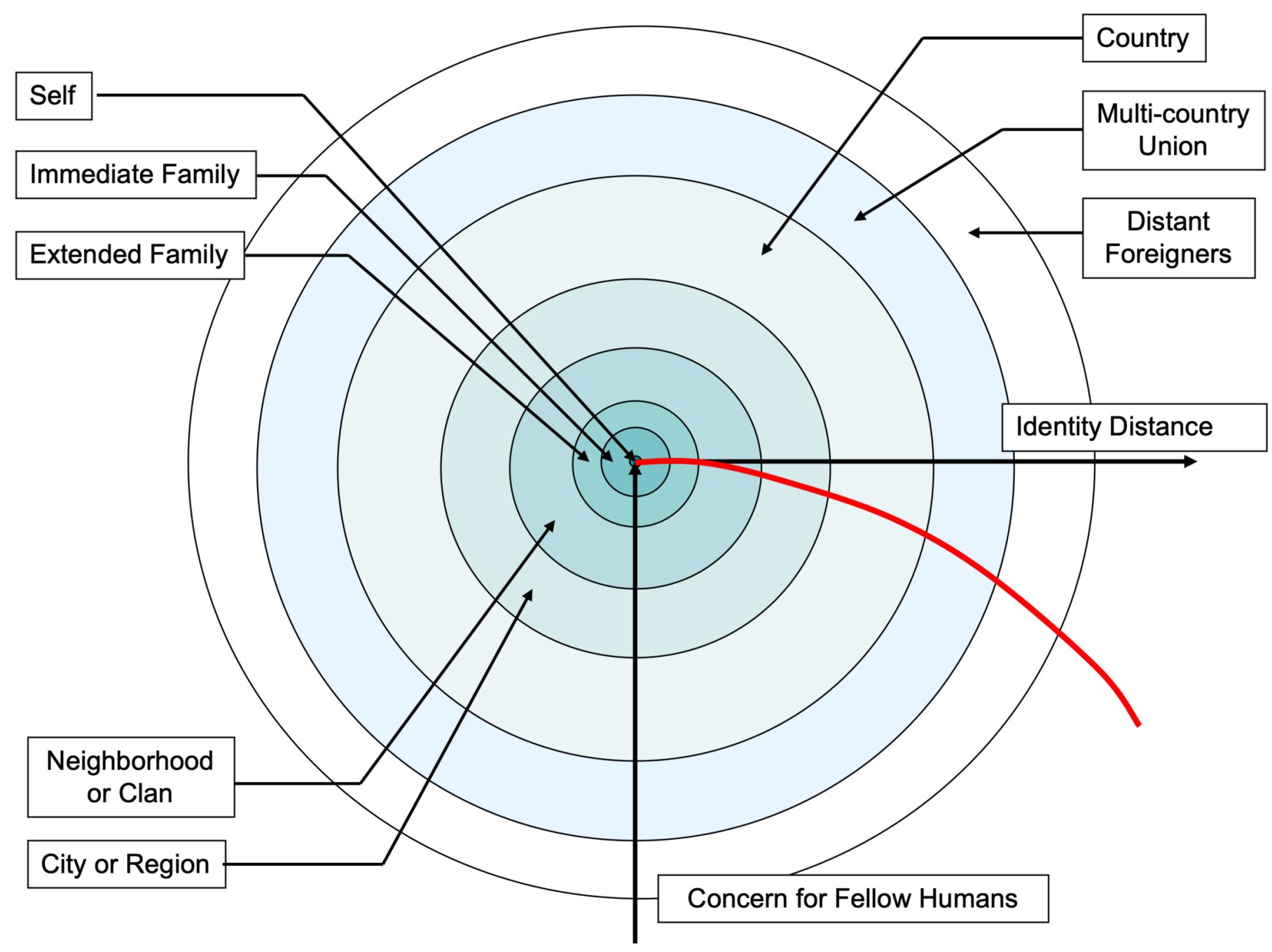

Figure 1: Circles of Identity and Feelings of Obligation

strength to the concept of a community where all nations can become saintly and deserving of similar rights regardless of their proximity.

Similarly, a major tenet of Hinduism is the concept of ahimsa, a Sanskrit word that defines non-violence, both to animals and humans. This is particularly strong in Jainism, dating to the $6^{\text {th }}$ century BCE, and is incorporated into the representation of an open palm with a wheel at its center. The wheel is the dharmacakra, a resolve to halt the inexorable cycle of reincarnation to which we are all condemned through a relentless pursuit of truth and non-violence. Buddhist philosophy emphasizes the cause and effect relationships implied by karma. Here again, one's goal is to end the recycle of birth and suffering through good deeds so we can reach Nirvana. In both cases, the obligation towards one's fellow humans is an integral element of maintaining harmony. Sikhism, a variant of Hindu philosophy and perhaps the only monotheistic religion in the ancient East, proclaimed that all humans are equal under God, and our right to life is constrained only by the obligation to care for others and share one's material possessions.

During the Middle Ages, scholars such as Erasmus of Rotterdam drew on cosmopolitan philosophy to advocate the ideals of world peace and universal rights. Arguing that humans are by nature sociable and prone to live in harmony with one another, Erasmus pleaded for national and re- ligious tolerance, and regarded all like-minded people as his fellow world citizens (Erasmus, 1986). Grotius, Hobbes, Pufendorf and others drew on natural law and social contract theories to lay the foundation for international law in a "great society of states" bound by a "law of nations" leading to a universality of rights and duties (Grotius, 1925).

The rise of capitalism as an economic force, the expansion of trade with the newly "discovered" lands in Africa, the Pacific and the Americas, the voyages of the great mariners, and the expansion of empires that reached across the globe during the Enlightenment contributed significantly to the spread of these ideas. But it was the acceptance of some fundamental "rights for all mankind" as enshrined in the American and French Revolutions that gave cosmopolitanism its greatest surge. The 1789 Declaration of Human Rights and the preamble to the American Constitution arose from cosmopolitan philosophy. Many of the leading lights of the Enlightenment - Voltaire, Montesquieu, Addison, Hume and Jefferson among them - identified themselves as cosmopolitans in the sense that they were not subservient to a particular political or religious philosophy, claimed to be free of cultural prejudices, and practiced tolerance and social broadmindedness.

Immanuel Kant was a strong advocate of such views. For him all rational beings were members of a single moral community, sharing aspirations for freedom, equality and 
independence within a system of self-governance and common laws. This precluded any form of tyranny, including slavery or colonial exploitation, considered contrary to the higher order of all humans. Whereas some political cosmopolitans advocated a single world state, Kant called for a more rational international order. He argued that global peace is only achievable when all states are organized along "republican" principles, group themselves into a voluntary "league of nations," and respect the human rights not only of their own citizens but also of foreigners (Kant, 1991).

The liberal economic concepts proposed by Adam Smith in The Theory of Moral Sentiments, and later in his Wealth of Nations, had a strong impact on cosmopolitan philosophy. Smith's view of a world of free trading nations, one in which markets and not governments catered to the needs of ordinary people, was very much in keeping with the primacy of the individual in cosmopolitan philosophy.

The formation of the United Nations and other multinational institutions in the modern era provided for the first time a legal and institutional framework that defines, however weakly, the rights and duties of the citizens of the world. Similarly, a number of actors formed either by civil society (NGOs) or in the economic sphere (multinational companies) have diminished the role and legitimacy of the nation state as the sole agent of political union.

One of the first acts of the United Nations was to adopt a Universal Declaration of Human Rights on December 10, 1948, which states that, "All human beings are born free and equal in dignity and rights. They are endowed with reason and conscience and should act towards one another in a spirit of brotherhood." Other UN Covenants expanded the sphere of human rights to many dimensions fundamental to modern concepts of liberty and the pursuit of happiness. ${ }^{3}$ More recently, the UN Global Compact, a voluntary agreement to which multinational companies may adhere, includes a set of ten "principles" by which the signatories promise to abide in managing their global operations. ${ }^{4}$ They constitute a set of obligations that global companies, and by definition their managers, must follow in order to fulfill their responsibility as global citizens.

Other supra-national institutions such as the International Criminal Court have emerged to provide individuals legal standing under international law that goes beyond those provided in national courts. Past cases against General Pinochet of Chile, various Serbian military commanders, and several African leaders are evidence of the increasing reach of this Court. Even national courts (such as the US' Alien Tort Claims statute) have increasingly prosecuted cases for wrongdoing that occurred in foreign jurisdictions by or against national citizens.

Perhaps the most significant change in recent years has been the rise of civil society groups and NGOs in the world scene (Kriegman, 2006). Some are spontaneous, such as against the WTO in Seattle in 1999, or in opposition to war in Iraq in 2003, or against global warming in 2019. Others are structured such as the World Social Forum (WSF), Amnesty International, the Red Cross and Red Crescent Societies, Médecins sans Frontières, and a host of other religious and lay organizations whose aim is to provide relief in the case of famine, medical emergencies or natural disasters, and who have adopted the cosmopolitan vision that we have a solemn duty to aid fellow human beings in need, regardless of nationality or distance.

Cosmopolitans do not advocate a subjugation of national identity to a bland universal mold. Culture is always fluid and evolving, and human societies have continuously traded goods, ideas, cuisine, music, games and people, while absorbing, blending, and innovating (Appiah, 2006). As Kriegman (2006) stated, "such hybridization makes it nearly impossible to delineate the boundaries of a specific culture. Cosmopolitanism rejects chauvinism and values diverse cultures, regarding all people of the earth as branches of a single family tree. The diffusion of this old consciousness in the new context of globalization is the basis for forging global citizenship."

The current backlash against globalization calls into question the very tenets of cosmopolitan thinking. The return to nativist policies across major regions (e.g., the US under Trump, Brexit in the UK, and populist parties in Europe, South America and Asia) rejects the notion that one has any responsibility for fellow humans when they belong to other ethnicities or countries, and have stood in opposition to granting sanctuary to political refugees and to economic immigrants. Those of us committed to a cosmopolitan viewpoint need to seek solutions to the problems that gave rise to this counterreaction and not simply abandon the principles of mutual responsibility (Rodrik, 2017).

There are some accepted precepts that should govern the actions of any self-proclaimed global citizen in the pursuit of his/her managerial responsibilities. Thus, a global citizen is one who abides by the following standards:

- Morally, a global citizen is one who comes to the aid of those in need, whether near or far, particularly in times of natural or man-made disasters; defends the universality of human rights; and opposes slavery or any subjugation of human beings by individuals, private or public organizations, or nation states.

- Politically, he/she fosters freedom of association, expression and political action; respects the right of workers to bargain collectively; takes into consideration his/her obligations toward environmental stewardship in all decisions; and fights corruption at all levels.

- Culturally, respects cultural, ethnic, religious and racial diversity in the workplace and in society; and combats discrimination in all its guises against minorities, women and other vulnerable groups.

- Economically, opposes any form of forced or child labor; promotes open and transparent business dealings; encourages the free flow of ideas, goods and services, capital and labor whenever possible, internally and across countries; and works towards the elimination of poverty by championing programs of inclusion and economic opportunity for the poor.

\footnotetext{
3 They include on Civil and Political Rights, on Economic, Social and Cultural Rights, the Geneva Convention, and conventions Against Genocide or Torture, on children's rights, and on gender discrimination.
}

4 www.unglobalcompact.org/AbouttheGC/TheTENPrinciples/index.html 


\section{SUSTAINABILITY AND THE INDIVIDUAL}

Sustainable development is essentially the effort to "meet the needs of the present without compromising the ability of future generations to meet their own needs" (Commission, 1987). Wanting something better for our children and grandchildren is not a new or rare concept and adds an inter-temporal dimension to the care expressed in Hierocles' circles. Global citizenship aims to reduce not only the discount rate applied to those distant from oneself, but also the rate applied to future generations.

Few of us over the age of 30, including the overwhelming majority of business and governmental leaders, were educated to understand today's complex, dynamic and interconnected world. Our old ways of learning may no longer be serving us well, particularly since the issues we now face are often a result of past decisions, from the deterioration of the environment to the deplorable state of world health. Peter Senge has promoted "a collective awakening to new possibilities that will change how people see the world, what they value, how society defines progress and organizes itself, and how institutions operate" (Senge, Smith, Kruschwitz, Laur, \& Schley, 2008: 5).

Whereas recent emphasis may focus on corporate global citizenship (Schwab, 2008; Tichy, McGill, \& Saint-Clair, 1997; Wood, Logsdon, Lewellyn, \& Davenport, 2006), we believe that greater consideration ought to be given to the role of the individual as a global citizen. Senge and his colleagues acknowledge the need to move beyond the concept of "triple bottom line" to one that emphasizes the "inner work of sustainability." Ideally, "comprehensive, integrated and holistic education will result in our acceptance of the interconnectedness of life on earth and lead us to take a greater responsibility for our actions and their impact on the whole" (Senge, Laur, Schley, \& Smith, 2006: 97-98). We have somehow gotten lost in the scientific method and devalued intuition at the expense of reason. We need to reclaim and "develop other forms of intelligence, including the intuitive, the emotional, the esthetic, and the spiritual" (Olalla, 2004: 66) if we are to succeed in this mission.

It is the acceptance of this responsibility that makes one a global citizen, and it is the commitment to collaboration that makes actions sustainable. John Zogby claims millennials are the "First Globals"; a world-wise generation that is the most outward looking, socially tolerant, and internationally aware of all times (Zogby, 2008). It should then be more expedient to teach these young men and women how to be global citizens than to try to change Baby Boomers into accepting greater responsibility as global citizens.

\section{CHARACTERISTICS, SKILLS, AND VALUES OF A GLOBAL CITIZEN}

If ensuring the sustainability of the earth is the responsibility of global citizens, then what skills and values must an individual possess so as to be justly held accountable? An exercise sponsored by Canada's International Development Agency argued for the importance of four characteristics of mental processes in global citizens: open-mindedness, full-mindedness, fair-mindedness, and world-mindedness. In other words, global citizens must be: (1) open to others' ideas and points of view, regardless of their identity distance; (2) able to foresee potential problems and recognize the limitations of judgment and the importance of balancing analysis with intuition; (3) impartial when dealing with others and not pre-judge them based on cultural or demographic characteristics; and (4) believe in "one world" (Case, 1997; Evans \& Reynolds, 2004).

Global competency must also include some level of language capability, cross-cultural communication skills, and the ability to find value in "something foreign" (Hunter, 2004). Global citizens need an understanding of world history, international relations, current events, and global political economy. Most importantly, they must promote values that support a love of and a commitment to humanity. ${ }^{5}$

Former UN Secretary General Kofi Annan asked a poignant question, "Do we have shared values?", that is, values that make cooperation easier and communication more effective (Annan, 2003). In 2000, the United Nations adopted the Millennium Declaration, which defined 8 goals on poverty eradication, world health, sustainable development and education to be achieved by 2015 . This was later replaced by 17 Sustainable Development Goals adopted in 2015 as a "blueprint to achieve a better and more sustainable future for all" by the year 2030 . Whereas not all countries are on track to meet these goals, considerable attention and funding has been committed to the endeavor by governments and NGOs. But individuals and private corporations must do their part. To remain silent and not take action is to condone the status quo, and to reject the responsibility of being a global citizen.

In summary, these are the skills and values global citizens must possess in order to act:

\section{CHARACTERISTICS AND SKILLS}

- cognitive abilities;

- courage to take action even under uncertainty;

- cross-cultural competencies, including multi-lingual proficiency;

- innovativeness and creativity;

- knowledge of global issues and their interdependencies;

- negotiation and conflict resolution skills;

- self-awareness and open-mindedness;

- a strategic (whole picture) perspective;

- systems thinking; and

- a willingness to challenge, be challenged, and to adapt.

\section{VALUES}

- a sense of justice and fair-mindedness;

- respect for human dignity;

- acceptance of diversity;

- a belief in the power of an individual's actions;

- commitment to the sustainability of the planet and all of its inhabitants;

- empathy and a sense of community;

- integrity;

- personal responsibility; and

- a commitment to life-long learning. 
Our next installment, at the end of this $A I B$ Insights issue, reviews how the work of business schools can foster these skills and values.

\section{ABOUT THE AUTHORS}

José R. de la Torre (delatorrejoser@gmail.com) is cofounder and Chair of the EMBA Consortium for Global Business Innovation, professor at Bologna Business School, and Founding Dean of FIU's Chapman Graduate School of Business where he held the JK Batten Chair in Strategy (now Emeritus). He previously taught at UCLA, INSEAD, and Georgia State after earning his doctorate from Harvard Business School. His research deals with the management of multinational firms, trust in inter-corporate collaborations and the importance of global citizenship.

Corinne Young (cyoung@fus.edu) is the Director of Graduate Studies at Franklin University Switzerland. She received her Ph.D. from Tulane University. Her research and teaching centers on designing and implementing transformational learning experiences in graduate management education. She focuses her work on developing responsible leaders in a stakeholder society. 


\section{REFERENCES}

Annan, K. 2003, December 24. Do We Still Have Universal Values? The Globalist.

Appiah, K. A. 2006. Cosmopolitanism: Ethics in a World of Strangers. London: Penguin Books.

Byers, M. 2005. Are you a Global Citizen? Really? What Does That Mean? The Tyee.

Case, R. 1997. Global Education: It's a Matter of Perspective. The Canadian Anthology of Social Studies: Issues and Strategies for Teachers. Burnaby, BC: Simon Fraser University.

Commission, B. 1987. Report of the World Commission on Environment and Development. General Assembly Resolution 42/187, New York: United Nations.

Dower, N. 2005. The Earth Charter and Global Citizenship: A Way Forward. Netherlands: Royal Tropical Institute.

Erasmus, D. 1986. A Complaint of Peace Spurned and Rejected by the Whole World. Erasmus: Works (originally published 1521), vol. 27: 289-322. Toronto: University of Toronto Press.

Evans, M., \& Reynolds, C. 2004. Educating for Global Citizenship in a Changing World. Toronto: Ontario Institute for Studies in Education.

Grotius, H. 1925. The Law of War and Peace (originally published 1625). New York: Bobbs-Merrill.

Hunter, W. D. 2004. Got Global Competency? International Educator, Spring: 10.

Kant, I. 1991. Perpetual Peace. In H. Reiss (Ed.), Political Writings (originally published 1795). Cambridge: Cambridge University Press.
Kriegman, O. 2006. Dawn of the Cosmopolitan: The Hope of a Global Citizens Movement. GTI Paper Series, 15. Cambridge, MA: Tellus Institute. https://do i.org/10.2139/ssrn.956184.

Nussbaum, M. C. 1997. Kant and Stoic Cosmopolitanism. Journal of Political Philosophy, 5(1): $1-25$.

Olalla, J. 2004. From Knowledge to Wisdom: Essays on the Crisis in Contemporary Learning. Boulder, CO: Newfield Network, Inc.

Rodrik, D. 2017. Straight Talk on Trade: Ideas for a Sane World Economy. Princeton, NJ: Princeton University Press. https://doi.org/10.2307/j.ctvc779z4.

Schwab, K. 2008. Global Corporate Citizenship: Working with Governments and Civil Society. Foreign Affairs, January/February.

Senge, P., Laur, J., Schley, S., \& Smith, B. 2006. Learning for Sustainability. Cambridge, MA: Society for Organizational Learning.

Senge, P., Smith, B., Kruschwitz, N., Laur, J., \& Schley, S. 2008. The Necessary Revolution: How Individuals and Organizations Are Working Together to Create a Sustainable World. New York: Doubleday.

Tichy, N. M., McGill, A. R., \& Saint-Clair, L. (Eds.). 1997. Corporate Global Citizenship. San Francisco, CA: The New Lexington Press.

Wood, D. J., Logsdon, J. M., Lewellyn, P. G., \& Davenport, K. 2006. Global Business Citizenship: A Transformative Framework for Ethics and Sustainable Capitalism. Armonk, NY: M. E. Sharpe.

Zogby, J. 2008. The Way We'll Be. New York: Random House. 